\title{
A biograi a de Monsenhor Luigi Pescarmona e as lutas sociais na Diocese de Guarabira-PB
}

\author{
Francisco Fagundes de Paiva Neto
}

\section{SciELO Books / SciELO Livros / SciELO Libros}

PAIVA NETO, FF. A biograi a de Monsenhor Luigi Pescarmona e as lutas sociais na Diocese de Guarabira-PB. In: OLIVEIRA, TB., org. Trabalho e trabalhadores no Nordeste: análises e perspectivas de pesquisas históricas em Alagoas, Pernambuco e Paraíba [online]. Campina Grande: EDUEPB, 2015, pp. 401-429. ISBN 978-85-7879-333-3. Available from SciELO Books $<\underline{\text { http://books.scielo.org }>\text {. }}$

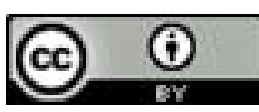

All the contents of this work, except where otherwise noted, is licensed under a Creative Commons Attribution 4.0 International license.

Todo o conteúdo deste trabalho, exceto quando houver ressalva, é publicado sob a licença Creative Commons Atribição 4.0.

Todo el contenido de esta obra, excepto donde se indique lo contrario, está bajo licencia de la licencia Creative Commons $\underline{\text { Reconocimento } 4.0 .}$ 


\section{A biografia de Monsenhor Luigi Pescarmona e as lutas sociais na Diocese de Guarabira-PB}

Francisco Fagundes de Paiva Neto

A história social ensina que não existe política social sem um movimento social capaz de impô-la, e que não é o mercado, como se tenta convencer hoje em dia, mas sim o movimento social que "civilizou" a economia de mercado, contribuindo ao mesmo tempo enormemente para sua eficiência.

Pierre Bourdieu

Ficamos com a responsabilidade de discutir, dentro da proposta de mesa-redonda intitulada "Lutas sociais em Guarabira: duas biografias", a participação do Monsenhor Luigi Pescarmona nas mobilizaçóes de camponeses na Comissão Pastoral da Terra, mormente, entre os anos de 1980 e 1990, em alguns municípios da Diocese de Guarabira, na Paraíba.

Nossa apresentação se assenta em uma pesquisa que realizamos durante o Doutorado sobre a biografia do padre em questáo, a partir da seguinte problemática: como se colocou o religioso diante de duas transiçóes passadas pela Igreja Católica no Século 
XX: o Concílio do Vaticano II, na década de 1960, e o avanço do neoconservadorismo católico na América Latina, a partir do papado de João Paulo II?

Nessa trajetória, tivemos uma série de cuidados, porque, comumente, a escrita da biografia de religiosos pode seguir dois percursos: ou tende à tradição hagiográfica, ou seja, das pessoas que são consideradas santas pela Igreja, em virtude da associaçáo da profissáo com a ascese ou com o sagrado ${ }^{1}$, ou, em virtude da participação de alguns religiosos no campo político, alguns biógrafos encontram substrato para elaboraçóes de hodiernos panegíricos ${ }^{2}$, quer à direita, quer à esquerda ${ }^{3}$. Por essa razão, buscamos nos aportes de Pierre Bourdieu ${ }^{4}$ a noção de trajetória, procurando analisar a biografia do sacerdote, desde suas alocaçóes e deslocamentos no campo religioso, até os níveis de integração e de conflitos com outros campos do espaço social, considerando, assim, as relaçôes presentes entre a religião e a política.

A trajetória religiosa e política do monsenhor Luigi Pescarmona sofreu impactos tanto do Concílio do Vaticano II - considerando

1 Ver: SILVEIRA, Ildefonso; REIS, Orlando dos (orgs.). São Francisco de Assis: escritos e biografias de São Francisco de Assis. Petrópolis: Vozes, 2000; FORTES, Carolina Fortes. A produção literária dominicana no Século XII: uma breve visão sobre a hagiografia. In: COSTA, Sandro da; SILVA, Andréia C. L. F. da; SILVA, Leila R. (orgs.). Atas do Ciclo: A Tradição Monástica e o Franciscanismo. Rio de Janeiro: UFRJ/IFCS, 2003; LE GOFF, Jacques. São Francisco de Assis. Rio de Janeiro: Record, 2001; LE GOFF, Jacques. Sáo Luís. Rio de Janeiro: Record, 2002.

2 Conforme o Littré Dictionnaire de la langue française, "o Panegírico exprime mais do que um elogio. O elogio contém, sem dúvida, o louvor da personagem, mas não exclui uma certa crítica, alguma censura. O panegírico não contém censura nem crítica" ("PANÉGYRIQUE, ÉLOGE: Panégyrique dit plus qu'éloge. L'éloge contient sans doute la louange du personnage, mais n'exclut pas une certaine critique, un certain blâme. Le panégyrique ne comporte ni blâme ni critique"). Ver: BOURDÉ, Guy; MARTIN, Hervé. As escolas históricas. Mira-Sintra; Mem Martins: Publicaçóes Europa-América, 1983; MORADIELLOS, Enrique. Las caras de Clío. Madri: Siglo XXI Editores, 2001.

3 Estabelecemos essa distinção a partir da associação desses religiosos com os campos políticos em questão: SOBREIRA, Azarias. O Patriarca de Juazeiro. Petrópolis: 1968; SANTANA, Manoel Henrique de Melo. Padre Cícero do Juazeiro: condenação e exclusão eclesial à reabilitação histórica. Maceió: EDUFAL, 2009; PEREIRA, Nilo. Dom Vital e a questáo religiosa no Brasil. Recife: Imprensa Universitária/UFPE, 1996; LE BRETON, Binka. Todos sabiam: a morte anunciada de Padre Josimo. Ediçōes Loyola, 2000; LE BRETON, Binka. A dádiva maior: a vida e a morte corajosas da irmã Dorothy Stang. Editora Globo, 2008; MURPHY, Roseanne. Mártir da Amazônia: a vida de Dorothy Stang. São Paulo: Paulus, 2008. Os religiosos receberam nesses títulos um sentido laudatório, tanto em virtude da vida política, quanto de perseguiçóes ou até mesmo do martírio.

4 BOURDIEU, Pierre. Razóes práticas. Campinas: Papirus, 1996. 
os seus matizes, que vão do desenvolvimentismo às relaçóes com a Teologia da Libertação (TL) ${ }^{5}$ - até o neoconservadorismo católico, cuja pujança refletiu, no lugar ocupado por nosso biografado no campo católico, uma convivência entre o trabalho na Comissão Pastoral da Terra (CPT) e as práticas assistencialistas em uma organização não governamental chamada "Comunidade Talita", responsável pelo trabalho de abrigar jovens do sexo feminino que enfrentaram situaçóes de violência sexual, a partir do ano 2000, e se prolonga até a presente data.

Não nos cabe lançar juízo de valor sobre a questão do assistencialismo católico, contudo percebemos, nessa prática, uma forma de aproximação com o Estado, que reflete uma relação política entre o Estado e a Igreja com fortes semelhanças com o período da neocristandade (1916-1955), sobretudo pela associação com políticos proeminentes da política (nacional ou estadual) para, através do beneplácito estatal, obter vantagens para a instituição ${ }^{6}$, fosse por meios materiais ou pela relação de reconhecimento social, demarcando, junto com as demais religióes, a importante manutenção e reprodução do capital simbólico católico. Diante dos limites de assistência social, coube à Igreja o trabalho assistencial realizado pelos religiosos ou leigos responsáveis por abrigos para idosos ou orfanatos. Mais recentemente, numa fase de mundialização da economia e do neoconservadorismo católico (entre os papados de João Paulo II e Bento XVI), encontramos uma entidade católica presidida pelo Monsenhor Pescarmona, a Comunidade Talita,

5 A TL forneceu um repertório de análise/prática a religiosos que optaram tanto pela via democrática quanto pela luta armada. Ver: BETTO, Frei. Batismo de sangue. Rio de Janeiro: 6.ed., Civilização Brasileira, 1983; CAMPO, German Guzman. Camilo, el cura guerrillero. Bogotá: Servicios Especiales de Prensa, 1967.

6 Conforme Scott Mainwaring (A Igreja Católica e a política no Brasil (1916-1985). São Paulo: Brasiliense, 1989, p. 43), a Igreja ficou fragilizada com a separaçáo do Estado, o laicismo e o cosmopolitismo no Brasil no início do Século XX, adotando a estratégia de reaproximar e de forjar uma nova aliança. Assim, a Igreja precisava lidar com sua fragilidade institucional sem modificar sua posiçáo conservadora na sociedade. No governo Vargas (19301945), quando chegou ao apogeu o modelo da neocristandade, a Igreja garantiu a influência católica no sistema educacional, na moralidade, no anticomunismo e no antiprotestantismo. Nessa fase, influiu ainda no sistema de comunicação; na organização dos trabalhadores urbanos (Círculos Operários e Juventude Operária); na gestáo da caridade, de orfanatos e abrigos para idosos, como missão social; na preservaçáo de uma rígida hierarquia entre os clérigos e os leigos etc. 
que, devido aos limites estatais, empreende práticas caritativas, com o apoio de voluntários e de auxílios públicos, influindo na assistência social a partir de novas práticas filantrópicas associativas entre Igreja e Estado, cujo efeito é uma sempre possível modalidade de clientelismo, conforme refere Cláudia Neves da Silva:

A década de 90 (...) trouxe uma nova perspectiva para a assistência social, que passou a figurar como política pública, constituindo-se o Estado como o grande responsável pelo enfrentamento à pobreza, e os usuários como cidadáos de direito, não sendo mais objeto da caridade de voluntários da sociedade civil. Porém, se no âmbito legal e do discurso houve essa ruptura com o cotidiano das ações assistenciais, verificamos que, se a lei e seus artigos apresentam um caráter não religioso, mas secular, garantindo direitos aos usuários da assistência, os voluntários- aqui nos referimos aos católicos - porque ainda são em maior número, continuam a atuar, mantendo uma certa hegemonia nas práticas e serviços nessa área, sob a perspectiva da caridade (...) Por esse motivo, avaliamos que é importante e necessário desmistificar a ideia, largamente difundida em nossa sociedade, de que assistência à população carente de bens e serviços deve pautar-se na concepçáo de caridade, a qual, inadvertida ou deliberadamente, é utilizada por diferentes atores sociais, subordinados ou não a uma instituição religiosa ${ }^{7}$.

A relação entre o catolicismo e o assistencialismo tende a ter uma reprodução em algumas instituiçôes, como a Comunidade Talita (em sincronia com as práticas instauradas na década de

7 SILVA, Claudia Neves da. Igreja católica, assistência social e caridade: aproximaçóes e divergências. Sociologias, Porto Alegre, ano 8, nº 15, jan.-jun. 2006, p. 349-350. 
1990), que também passa a ser um espaço de disputa e busca por legitimidade de diversos grupos sociais ${ }^{8}$. Náo obstante, para fins de elaborar este texto em sintonia com a proposta da organização do evento, bem como pela exiguidade do espaço, lançaremos o nosso olhar sobre a fase das mobilizaçóes do religioso com a questão agrária.

\section{Trajetória religiosa-política: ambiências sociais e experiências do habitus partisáo}

Na década de 1960, aportaram no Brasil vários grupos de religiosos estrangeiros, principalmente europeus, que se estabeleceram nas mais variadas regióes do país. Muitos desses padres e freiras chegaram aos trópicos imbuídos de uma ação clerical orientada pelos princípios do Concílio do Vaticano II (1962-1965), caracterizado pelo ecumenismo e pela descentralizaçáo, e que se chocava com os padróes do catolicismo tradicional, afeito ao centralismo, especialmente, por causa das tensóes originadas do liberalismo, do socialismo, do comunismo e das igrejas protestantes.

Realizamos um trabalho de história oral de vida, através de entrevistas semiestruturadas, com um padre italiano chamado Luigi Alberto Pescarmona, cuja primeira área de atuação no Brasil foi Teófilo Otoni (Minas Gerais), onde acompanhou, na década de 1960, as populaçóes de trabalhadores das minas e camponeses. Muitos desses trabalhadores realizaram migraçóes em decorrência da crise do setor minerador. Para isso, elegeram como destino a Regiáo Norte ou áreas metropolitanas, devido à violência no campo.

Depois dessa fase, o Padre Pescarmona transferiu-se para o estado da Paraíba, no fim da década de 1970, e radicou-se na área sob a responsabilidade do Bispo auxiliar, D. Marcelo Carvalheira. Quanto ao caráter mais específico deste trabalho, algumas questôes nortearam nossa abordagem: como se deu a militância política de um padre estrangeiro no agreste paraibano nas décadas

8 PAIVA NETO, Francisco Fagundes. A trajetória religiosa-política do padre Luigi Pescarmona (1960-2000): entre o habitus partisão e o assistencial. Campina Grande: Tese de Doutorado em Ciências Sociais/Universidade Federal de Campina Grande, 2012. 
de 1980 e 1990 ? Quais os limites dessa prática nas fronteiras dos campos político e religioso? Como um conflito no campo religioso também foi instaurado? Assim, objetivamos analisar como foi feita a prática de um agente da Teologia da Libertação (TL) em uma área, até entáo, pautada pelo catolicismo de bases anteriores ao Vaticano II.

Nosso primeiro contato com o Padre Luigi Pescarmona foi no ano de 2004, quando fizemos algumas incursôes na Comissão Pastoral da Terra (CPT), com o objetivo de visualizar a dinâmica da atuação da Igreja na área da Diocese de Guarabira, na Paraíba. Encontramo-nos no momento de uma refeição e tomamos uns goles de café juntos, enquanto conversamos animadamente sobre as razóes de minha presença na CPT, fazendo leituras de recortes de jornais e de relatórios. O padre, entáo, abriu um flanco a partir de narrativas sobre a questáo agrária na Paraíba e o seu envolvimento com as áreas de conflito. Elaboramos um projeto e o procuramos para outra conversaçáo, em que fizemos o convite para realizar a série de entrevistas, que ocorreram na sala de reunião da CPT (quando os serviços e as pastorais se concentravam em um prédio vizinho ao Palácio Episcopal, nas proximidades da Catedral de Guarabira) e, eventualmente, na residência do padre ou na Comunidade Talita. $\mathrm{O}$ trabalho de entrevistas prolongou-se por cerca de um ano e, no fim, submetemos as transcriçóes para eventuais correçóes, que demandaram novas entrevistas, visando esclarecimentos. Isso prolongou mais um pouco o trabalho e, por fim, obtivemos um documento firmado em cartório, autorizando a publicaçáo de trechos ou da totalidade dos registros.

A opção pelo estudo da trajetória associou-se à metodologia da história oral com o cruzamento de outras fontes em nossa pesquisa: jornais, relatórios, processos-crimes, cartas e trabalhos acadêmicos. Quanto à história oral, buscamos em Saltalamacchia dois fundamentos metodológicos: o primeiro, a questão do "sentido", e o segundo, o caráter da coinvestigação. O termo "sentido" é definido como

el lugar que ocupan los hechos en la "estructura 
de relevancias" que organizan la percepción activa del sujeto. Esa estructura de relevancias está fundada (...) en los valores, saberes y certezas que, según se supone, el interpelado comparte, en algunos casos, con casi todos sus contemporáneos y en otros con sólo algunos de ellos (...) La historia de vida permite preguntar al entrevistado sobre ese sentido particular que para él tuvieron los actos en el momento de ocurrir?.

Essa é uma forma de estabelecer possibilidades de análise dos conteúdos da memória. Já o caráter da coprodução nos sugere uma experiência de pesquisa em que se visualiza o contexto a partir de um caráter dinâmico, fruto das relaçóes do indivíduo com diversos campos sociais com os quais se relaciona. Assim, a pesquisa aponta para alguns focos, em que

el entrevistador (...) aportará a las entrevistas sus instrumentos analíticos, su entrenamiento en el análisis de situaciones y un conocimiento quizás más global sobre el proceso; conocimiento logrado tanto mediante el previo estudio de fuentes secundarias como de otras entrevistas (...) La entrevista debe ser entendida como el marco de una elaboración teórica conjunta en la que no necesariamente surgirán acuerdos totales o aprovechamientos semejantes; pero sí interpretaciones que no existían antes de la relación hipotéticamente un alerta sobre los posibles efectos del paso del tiempo en la estructuración del recuerdo; se pueden analizar las posibles alteraciones que provengan de las varías interferencias a las que nos refiriéramos en el apartado anterior ${ }^{10}$.

9 SALTALAMACCHIA, Homero. La Historia de Vida: reflexiones a partir de una experiencia de investigación. Puerto Rico: Ediciones SIJUP, 1992.

Ibidem. 
A questão da coprodução permite um conjunto de análises e a aplicaçáo dos critérios éticos exigidos pela história oral, pois nem todas as memórias, mesmo quando narradas, são publicadas, e isso exige o estabelecimento de um acordo entre entrevistador e entrevistado. A partir dessas possibilidades metodológicas, realizamos pesquisas em outras fontes, visando construir um conjunto de referências para perscrutar a participaçáo do Padre Luigi Pescarmona na CPT e sua relação com os conflitos no campo. Alguns eixos, inicialmente, fizeram gravitar nossas entrevistas: a vida na Itália na fase da II Guerra Mundial (II GM) e o início da vida como padre no Brasil nos anos 1960. As duas temporalidades nos traziam uma série de imagens a partir das narrativas do padre, cuja família tinha vínculo com a resistência italiana ao fascismo, através dos grupos de guerrilheiros partigiani (constituídos por uma variedade de tendências políticas, como católicos, liberais, socialistas e comunistas) atuantes em várias frentes. $\mathrm{O}$ segundo eixo nos fez dialogar longamente sobre sua formação de padre durante o Concílio do Vaticano II e sua preparação para atuar no Brasil. Posteriormente, detivemo-nos em sua militância na CPT e junto aos camponeses da Paraíba.

As narrativas sobre a infância nos arrabaldes da cidade de Alba (Cuneo), regiáo do Piemonte, no curso da II GM, com o desenvolvimento de uma série de conflitos entre os partigiani e as tropas nazifascistas ${ }^{11}$, deram-nos condiçóes para perceber a formação de um habitus ${ }^{12}$ relacionado às questôes sociais. A Diocese de Alba teve uma especificidade no contexto político italiano: a

11 Tratamos dessa questão em um artigo publicado com o título: PAIVA NETO, Francisco Fagundes. A Ação Católica: a resistência piemontesa ao fascismo (1933-1944). Histórica Revista Eletrônica do Arquivo Público do Estado de Sáo Paulo, n.58, maio 2013.

12 A noção de habitus, para Pierre Bourdieu (Esboço da teoria da prática. In: ORTIZ, Renato (org.). Pierre Bourdieu - Sociologia. Trad. Paula Monteiro. São Paulo: 2.ed., Ática, 1994, p. 61), é a de um "sistema de disposiçôes duráveis, estruturas estruturadas predispostas a funcionar como estruturas estruturantes, isto é, como princípio gerador e estruturador das práticas e das representaçóes que podem ser objetivamente 'regulamentada' e 'reguladas' sem ser o produto de obediência a regras, objetivamente adaptadas a seu fim sem supor a intenção consciente dos fins e o domínio expresso das operaçôes necessárias para atingi-los e coletivamente orquestradas, sem ser o produto ação organizadora de um regente". Aqui, encontramos uma tensão entre o indivíduo e a estrutura social, pois o habitus é produto, mas é igualmente produtor como um princípio gerador de práticas e representaçóes. 
presença de D. Luigi Grassi, cuja proximidade com os guerrilheiros do Norte da Itália o fez ficar conhecido como o "bispo partisão"13. Ademais, a condição de camponês trabalhador ${ }^{14}$, em Canale D'Alba ${ }^{15}$ de Cesare Pescarmona (pai de Luigi Pescarmona), de opção política socialista e membro da resistência (na condição de apoiador), possibilitou a convivência com processos sociais relacionados às experiências de classe do campesinato e do operariado piemontês, bem como à formação de uma memória sobre lutas sociais. $\mathrm{O}$ contato com um contexto social marcado pela exploração figura como um estímulo ao trabalho de memória sobre a experiência paterna (e dos demais trabalhadores) e de suas modalidades organizativas. Os camponeses-trabalhadores, os "braccianti" e demais camponeses proletarizados fizeram parte de um contexto de conflitualidade, que aflorou na memória do religioso por sua relação familiar, a partir dos enleios com a participação política. Esse fato pode estar associado a algumas questóes da experiência e das vicissitudes apontadas na biografia por Giovanni Levi do padre piemontês Giovan Battista Chiesa, um exorcista do Século XVIII ${ }^{16}$. De acordo com Jacques Revel,

13 Cf. GRASSI, Luigi Maria. La tortura di Alba e dell'albense (1944-1945). Alba: San Paolo, 3.ed., 1994.

14 O camponês trabalhador tem as seguintes características: 1) Sua condição é de uma adaptação permanente e de longa duração, que tem emergido em resposta às mudanças estruturais dentro das sociedades industriais. Essa categoria é histórica, tem existido desde o Século XVIII, na Itália, e se desenvolvido desde a II GM; 2). É um processo que se relaciona com a dinâmica familiar e as fases da vida, tais como casamento, reprodução, educação de crianças e aposentadoria; 3) Os camponeses-trabalhadores persistem ao longo da geraçóes. (Cf. HOLMES, D. R. A peasant-worker model in a northern Italian context. In: American Ethonologist, v. 10, n. 4, nov. 1983, p. 734-748 apud MENEZES, Marilda Aparecida de. Redes e enredos nas trilhas dos migrantes. Rio de Janeiro: Relume Dumará; Joáo Pessoa: EDUFPB, 2002, p. 46.). Essa classificação define um proletário de uma aldeia, cujos rendimentos são obtidos fora da sua comunidade. $\mathrm{O}$ camponês-trabalhador realiza trabalhos não agrícolas na cidade e ofícios agrícolas em sua aldeia por longas horas. $\mathrm{O}$ cultivo de uvas e a atividade vinícola eram conhecidos pelos Pescarmona, mas Cesare Pescarmona também trabalhava numa empresa de farináceos.

15 Alba localiza-se próximo a Turim, centro de agitaçóes operárias na década de 1920.

16 O título do livro de Giovanni Levi, A herança imaterial: trajetória de um exorcista no Piemonte do Século XVII. (Tradução: Cynthia M. de Oliveira. Rio de Janeiro: Civilização Brasileira, 2000), refere-se ao prestígio do pai, que foi herdado pelo padre Chiesa. O prestígio foi resultante da rede de relaçóes de propriedade e de todo o jogo de influências no tocante ao exercício do poder em Santena e região. Assim, o padre Chiesa está enredado nesse contexto maior em que, a rigor, os exorcismos praticados figuram como uma espécie ponto de partida para explorar uma realidade mais profunda. 
Todas as estratégias pessoais e familiares talvez tendam a parecer atenuadas em meio a um resultado comum de relativo equilíbrio. Todavia, a participação de cada um na história geral e na formação e modificação das estruturas essenciais na realidade social não pode ser avaliada somente com base nos resultados perceptíveis: durante a vida de cada um aparecem, ciclicamente, problemas, incertezas, escolhas, enfim, uma política da vida cotidiana cujo centro é a utilização estratégica das normas sociais. A intenção anuncia-se claramente: a abordagem micro-histórica deve permitir o enriquecimento da análise social, torná-la mais complexa, pois leva em conta aspectos diferentes, inesperados, multiplicados pela experiência coletiva ${ }^{17}$.

No caso do exorcista piemontês, Giovan Chiesa, as questôes que lhe tocavam mais diretamente diziam respeito às estratégias do religioso na Igreja e na aldeia de Santena, em uma regiáo afetada por conflitos entre camponeses, entre as perspectivas em torno do sagrado e da política referente às tensões das comunidades diante da centralização estatal ${ }^{18}$.

Em relação ao padre Luigi Pescarmona, essas interaçóes passavam também pelas questóes de ordem política, pois atualizavam alguns aspectos experienciados pelo próprio religioso na fase em que viveu na casa paterna. Em nossa pesquisa, chamamos esse habitus de "partisaao" por sua relação com uma experiência política e de classe. Realizando um estudo sobre memórias, Connerton $^{19}$ visualizou como a memória pode motivar açôes em indivíduos, no sentido de se tornarem herdeiros dos acontecimentos

17 REVEL, Jacques. A história ao rés-do-chão. In: LEVI, Giovanni. A herança..., op. cit., p. 18.

18 GRIBAUDI, Maurizio. Escala, pertinência, configuração. In: REVEL, J. (org.). Jogos de escala. Rio de Janeiro: Editora FVG, 1998, p. 129.

19 CONNERTON, Paul. Como as sociedades recordam. Lisboa: Celta, 1993, p. 47-48. 
marcantes de sua classe. $\mathrm{O}$ ato de lembrar e de expressar para outrem uma memória (através da palavra ou dos atos políticos) expressa a constituição de um passado em que se gestou um habitus de classe passível também de ressignificação na própria performance de um religioso empenhado em uma pastoral relacionada à reforma agrária. Assim, o habitus é estruturado e estruturante, como um ato de rememorar, e conjuga tempos verbais pretéritos e do presente. Isso explica que, embora um indivíduo tenha como profissão a vida religiosa, podemos perceber elementos relacionados a um habitus de classe por meio da própria socialização primária relacionada à experiência familiar. Esse habitus faz vibrar no tempo presente vozes e ecos do passado.

É necessário levarmos em conta a importância da oposição da população piemontesa ao fascismo. Essa área, devido à sua industrialização, tinha uma forte tradição comunista entre os trabalhadores urbanos e nas áreas rurais ocorreram conflitos sociais intensos, que foram duramente reprimidos pelos fascistas entre 1918 e $1922^{20}$. O norte italiano tinha o seu cotidiano marcado pelo movimento operário com uma organização sindical e partidária fortemente vascularizada, responsável pela eleição parlamentar do próprio Antonio Gramsci ${ }^{21}$, na fase anterior ao fascismo ${ }^{22}$. Porém, a partir de 1944, a presença das tropas aliadas no sul da Itália desestabilizou o governo fascista. Assim, houve açóes de tropas regulares e a adesão de muitos civis aos grupos da resistência que, com ataques em diversas áreas, capilarizaram as açóes bélicas sufocando os nazifascistas. Avaliando os movimentos de resistência europeus, Hobsbawm caracterizou uma diversidade e níveis de participação:

Duas coisas se deve dizer (...). Primeiro, sua importância militar (com a possível exceçáo da Rússia) foi insignificante antes de a Itália retirar-se da guerra em 1943, e não decisiva em parte alguma,

20 SASSOON, Donald. Mussolini e a ascensão do fascismo. Tradução Clóvis Marques. Rio de Janeiro: Agir, 2009, p. 24.

21 MAESTRI, Mário e CANDREVA, L. Antonio Gramsci. São Paulo: Expressão Popular, 2001.

22 Sobre o fascismo como regime (1926-1943), sugerimos a leitura de: LUPO, Salvatore. II fascismo: la politica in um regime totalitario. Roma: Donzelli Editore, 2005. 
com exceção talvez de partes dos Bálcấs. Deve-se repetir que seu significado foi político e moral. Assim, a vida pública italiana foi transformada, após mais de vinte anos e um fascismo que desfrutara de considerável apoio até mesmo entre os intelectuais, pela mobilização impressionante e generalizada da Resistência em 1943-45, incluindo um movimento partisan armado no Centro e Norte da Itália de por volta de $100 \mathrm{mil} \mathrm{com-}$ batentes, com 45 mil mortos (...) Enquanto os italianos podiam deixar a memória de Mussolini para trás com a consciência limpa, os alemães, que tinham apoiado o seu governo até o fim, não podiam colocar distância entre eles próprios e a era nazista de 1939-45 (...) A segunda observação sobre a Resistência é que (...) com a notável exceção da Polônia, sua política pendia para a esquerda. Em cada país os fascistas, os radicais de direita, os conservadores, ricos locais e outros cujo principal terror era a revolução social, tendiam a simpatizar, ou pelo menos náo se opor aos alemães (...). O mesmo, não se deve esquecer, fizeram os elementos profunda e intransigentemente anticomunistas na Igreja Católica e seus exércitos de religiosos convencionais, embora a política da Igreja fosse demasiado complexa para ser classificada simplesmente como 'colaboracionista' em qualquer parte ${ }^{23}$.

Essas considerações nos aguçam a perceber a existência de brechas na sociedade italiana que, mesmo sob as violências do regime fascista, pôde dar uma demonstração de resistência política a partir de grupos de civis em armas, demonstrando como as açóes dos partigiani junto com os aliados foram eficazes para a derrota de Mussolini em 1945.

23 HOBSBAWM, Eric. Era dos extremos: o breve Século XX. São Paulo: Companhia das Letras, 1995, p. 165-166. 
Com o fim da guerra, o esforço para reconstruir a sociedade italiana tomou corpo, por meio de um processo de pacificação que envolveu vários agentes políticos: a Democracia Cristá, os socialistas e os comunistas. Sobre a reestruturação italiana depois da II GM, obtivemos algumas referências que demonstram o nível de participação na política: os traumas em relação ao fascismo e os temores diante de outro governo que pudesse flertar com uma feição autoritária, no caso específico dos comunistas simpáticos a Iosif Stalin. Segundo o Padre Luigi Pescarmona,

as eleiçóes de 1948, que foram decisivas para a Itália, porque havia a possibilidade do comunismo entrar pela ideia, por eleiçáo na Itália. E não entrou por acaso. Então o comunismo ficou por quarenta anos numa oposição legal, firme, mas sem revolução numa atuação mesmo partidária. Estavam numa oposição democrática. Mas em 1948, os comunistas estavam na hora de ganhar, mas erraram no modo de fazer a propaganda, a publicidade. Salientaram muito o eliminaremos: eliminaremos a Igreja, eliminaremos náo sei o quê. Então não calcularam a base católica histórica da Itália, que (...) Antonio Gramsci dizia: $\mathrm{Na}$ Itália o comunismo tem que tomar conta, tem que calcular que a base é católica. Se tivessem observado essa parte e eliminado as críticas à religião, à Igreja (...) Porque qualquer italiano como comunista manda os filhos estudar em escolas católicas (...) Foi nesse clima de efervescência política, no ano de 1948, quando eu ainda era criança, que ficava circulando pelas ruas e presenciando as manifestaçóes políticas na minha cidade.

É importante ressaltar que as disputas entre os comunistas e os fascistas foram táo acentuadas nos anos anteriores à II GM 
quanto nos posteriores $^{24}$. Um aspecto significativo para a constituição da trajetória de vida do Padre Pescarmona foram as socializaçóes primárias e as secundárias firmadas ou tangenciadas em campos políticos sinalizados pela esquerda. Essa condiçáo permite-nos referenciar, a partir de Fentress e Wickham ${ }^{25}$, que a memória é sempre social, pois os homens não são autômatos, mas relativamente autônomos diante das instituições sociais. Por outro lado, é necessário considerar uma dimensão da memória cuja expressão também se delimite pela herança dos acontecimentos marcantes da classe no núcleo familiar ${ }^{26}$. Inicialmente, a casa junto com o pai, um socialista; na sequência, as experiências em Minas Gerais durante a ditadura militar; e, por fim, os vínculos com os movimentos políticos dos camponeses na Paraíba. Embora esses vínculos tenham sido estabelecidos com os grupos de esquerda, havemos de perceber uma relação de equidistância, na medida em que o próprio Concílio do Vaticano II fazia críticas ao capitalismo no sentido de reformá-lo para garantir a dignidade entre os homens.

A Igreja, ciente do caráter universalista da religião, não quis se prender à dimensão de exclusividade para uma "classe", mas para o seu rebanho, sem fazer distinçóes. Esse foi o primeiro ponto que identificamos, no que se refere aos limites da TL entre os religiosos e no caso do Monsenhor Pescarmona, especificamente. Um dos fatores confirmadores dessa nossa análise foi a nova romanização realizada pelo Papa João Paulo II, cujo alvo foi a TL, o que implicou sançôes contra alguns teólogos e a saída de outros de suas fileiras, como Leonardo Boff. Entre os leigos, esse fator resultou na formação de um movimento social com um maior

24 No ano de 1969, a Itália vivenciou o chamado "Outono quente", em virtude de greves e ocupações de fábricas pelos membros dos Conselhos de Fábrica. Em meio às tensốes com os setores políticos conservadores, os neofascistas e os serviços secretos italianos e dos EUA, ocorreu uma violenta repressão, que acentuou o ânimo de setores comunistas que ingressaram nas Brigadas Vermelhas e no Poder Operário com práticas de política armada até o começo da década de 1970. Cf. MODONESI, Massimo. Subalternidade, antagonismo, autonomia. Buenos Aires: Consejo Latinoamericano de Ciencias Sociales - CLACSO; Prometeo Libros, 2010.

25 FENTRESS, James e WICKHAM, Chris. Memória social. Lisboa: Teorema, 1992.

26 CONNERTON, Paul. Como as sociedades..., op. cit. 
quantum de autonomia, mesmo mantendo abertura para dialogar com a Confederação Nacional dos Bispos do Brasil (CNBB) e com a CPT. Estamos nos referindo ao Movimento dos Trabalhadores Rurais Sem Terra (MST).

O segundo eixo das nossas entrevistas foi o da formação contemporânea ao Vaticano II e sua vinda para o Brasil. Aqui nos defrontamos com alguns elementos sobre uma rígida formação em um seminário italiano, às expensas do pai e de um irmão. $\mathrm{O}$ monsenhor nos destacou a qualidade da formaçáo proporcionada aos seminaristas, pois o seminário tinha professores de renomadas universidades europeias, como as de Budapeste, de Louvain ou de outras localizadas na Alemanha, conforme mostra este trecho da entrevista:

Eu entrei para o seminário com catorze anos. Pelos meus cálculos foi por volta de 1951-52 (...) Então eu quis continuar no seminário, que era pago, tal qual um colégio particular. Os estudos no seminário eram caros. Diziam-me às vezes: Você não vai pagar! (risos). Mas eu recebi ajuda, né? Recebi ajuda de papai, do meu irmão, logo depois de mim, que trabalhava muito para me ajudar a dar conta dos estudos, para pagar o seminário, os livros... No período em que estava no seminário me senti influenciado (...) com dois grandes representantes da democracia-cristâ: a Itália, com De Gasper, e a Alemanha, com Adenauer. Os dois fundaram o Partido Democrata-Cristão (...) e conseguiram grande popularidade. Ambos eram remanescentes de grupos de resistência ao fascismo e ao nazismo. E os dois eram católicos fervorosos.

Encontramos mais elementos para entender uma formação religiosa atenta às questôes políticas do mundo inteiro. Mas a entrevista nos faz depreender que, mesmo tendo a influência paterna 
socialista, o campo religioso católico, representado pela democracia cristá, promoveu um grau de erosão em relação ao pensamento político de esquerda. Provavelmente, os traumas da II GM vivenciados pela sociedade europeia colaboraram para reflexóes em instituiçôes como a Igreja Católica, que sentiu a necessidade de um aggiornamento por meio de um novo concílio, o que pôde influir no curso da política por meio de um partido próprio: a Democracia Cristá, que, a rigor, distanciava-se de qualquer modalidade de experiência política socialista. Então, sempre é necessário, de acordo com a dinâmica da trajetória social de um indivíduo, ter a acuidade para se verificar o nível de tensão com a estrutura, ou, em outros termos, de um indivíduo com o campo. A relaçáo entre determinado habitus e o campo em que o indivíduo se movimenta pode representar tanto a manutençáo de uma dada estrutura social quanto sua reversão. Conforme a reflexão de Giovanni Levi,

Não se pode negar que há um estilo próprio a uma época, um habitus resultante de experiências comuns e reiteradas, assim como há um estilo próprio de um grupo. Mas para todo indivíduo existe também uma considerável margem de liberdade que se origina precisamente das incoerências e confins sociais e que suscita a mudança social ${ }^{27}$.

Assim, destacamos que, mediante as condiçõos sociais, o campo de possibilidades pode se apresentar com brechas, cuja mobilização de determinado grupo/classe social pode manifestar estratégias específicas quanto à ordem social. Em outro momento das entrevistas, o padre mencionou as reflexôes sobre a história contemporânea durante o período de formaçáo religiosa, como mostra este fragmento:

No nosso seminário, havia uma ligação muito

27 LEVI, Giovanni. Usos da biografia. In: FERREIRA, Marieta Moraes; AMADO, Janaína. Usos e abusos da história oral. Rio de Janeiro: Editora da FGV, 1996, p. 182. 
grande com a história contemporânea. Recebíamos informaçóes explícitas (...) sobre os diversos países: sobre a China, a Iugoslávia, a Rússia, a África, a América do Norte (...) Todo o movimento político ou de revolução ou de blocos (...) Nós sabíamos, líamos... Por exemplo, eu era um não-alinhado sobre pensamento, entre os blocos, do Muro de Berlim para lá e para cá! Eu era um não-alinhado! Eu acompanhava com atenção os países, que estavam emergindo, a exemplo da Iugoslávia, do Egito de Nasser, da Argélia de Ben Bella (...) Procurei manter vivo o meu senso crítico em todos os momentos ${ }^{28}$.

Ao que parece, a Igreja realizou, em alguns seminários, um trabalho preparatório para os novos desafios oriundos do pósguerra, considerando a bipolaridade decorrente das tensóes entre os EUA e a URSS e os seus aliados. Em uma escala de análise voltada para o contexto italiano, deve-se levar em conta a busca pela Igreja de garantir a autonomia diante do Estado italiano e das tentativas intervencionistas como as de Mussolini. Sobre os embates políticos na década de 1960 na Itália, o Padre Pescarmona rememorou:

E quando, em 1960, houve um governo filofascista, isto é, depois de anos e anos as pessoas voltavam a defender ideias fascistas. Eu me lembro que era um seminarista, perto já da batina, e fui para uma manifestação em Parma (...) para demonstrar o meu repúdio ao fascismo. Fui com um grupo de seminaristas para participar de uma manifestação (...) Havia tambores, tambores, que fazia muito barulho para demonstrar a indignação dos manifestantes contra as ideias da 
extrema-direita (...) Fui ordenado em setembro de 1961, em Alba. Lembrando que o Concílio de Vaticano II iniciou em 1962. E eu estreei no Brasil em 1966 29.

A vinda para o Brasil foi fruto de alguns contatos, no ano de 1965, com o bispo de uma Diocese recém-criada, a de Teófilo Otoni, em Minas Gerais, que estava participando do Concílio do Vaticano. A nova diocese necessitava de padres devido à dispersão da populaçáo. A Igreja realizava cursos preparatórios para os padres que vinham para a América Latina, conforme esta narrativa:

Informei-me e fique sabendo que havia um curso, em Roma, de preparação para América Latina, com quinze dias de atividades. E logo me inscrevi. Era em setembro-outubro. Fiz estudos sobre a América do Sul e o Brasil, também. Não me falaram nada do golpe de Estado. Estudamos mais os aspectos sociológicos e religiosos. Não falaram nada do político. Acho que não haviam ainda se dado conta ainda, pois estávamos em 1965 e o golpe havia ocorrido em 1964 (...) Ainda era inicial. E também a Igreja, com medo do comunismo, não percebeu onde havia caído. Então nos quinze dias, estudamos a sociologia das religióes do Brasil, as cidades. E eu, então em 1965, aceitei e fiz um contrato com o bispo, que me enviava na Itália, e com o bispo, que me recebia, e me aceitava em Minas Gerais ${ }^{30}$.

Provavelmente, como os mestres da Igreja se encontravam em uma fase de transição, não se detiveram na discussão sobre os golpes de Estado na América Latina, buscando uma convivência dos religiosos com a ordem política, ou tenham acreditado que o

29 Idem.

30 Idem. 
terrorismo de Estado não fosse estimular a ativa participação de membros do clero com organizaçóes de esquerda. $\mathrm{O}$ trabalho do padre, como certamente de tantos outros, foi feito no sentido de atender, mais imediatamente, às necessidades espirituais dos fiéis da paróquia, como foi rememorado:

Por isso, os primeiros anos foram só de adaptação, de conhecimento (...) Então, em 1969 não havia uma linha, havia uma abertura. Escutava, lia, participava de encontros. Mas depois de 69, em 70 eu estava decidido em participar em uma linha popular de mudança de governo. Havia uma necessidade premente de se constituir no Brasil um governo que verdadeiramente criasse oportunidades para todos. E também procurei me aproximar mais dos estudantes e dos trabalhadores. Nos anos 60 em Minas Gerais, já havia feito a sua expulsão de pequenos produtores e sitiantes dos campos. E os campos estavam cheios de fazendas, quase que vazias de pessoal. A diferença é que no Nordeste a expulsão é posterior. Aqui os campos ainda estavam cheios de famílias. Lá em Minas muitos haviam partido para Rondônia, para o Maranháo, por conta do projeto do governo militar de Integrar para não entregar (...) E depois aquele projeto do governo tornou-se um fracasso ${ }^{31}$.

A narrativa demonstra problemas sociais referentes aos trabalhadores desprovidos de terra e que se viram obrigados a migrar para outros estados ou a permanecer num processo de marginalização social nos subúrbios das cidades médias ou de grande porte. A indignação com as dificuldades oriundas do modelo econômico adotado pelos militares dava claros sinais, através das 
migraçóes, que resultavam na fragilização de comunidades e pelo fato de acentuar as condiçóes de miséria e de pobreza, além de comprometer o próprio trabalho religioso. O fim da década de 1960 serviu como uma primeira experiência para se perceberem os problemas de ordem social no Brasil. Queremos salientar um ponto em relação à citação passada, quanto à pergunta feita sobre a participação política no Brasil: a referência à decisão de participar de uma linha popular de mudança de governo e a "necessidade premente de se constituir no Brasil um governo que verdadeiramente criasse oportunidades para todos". Essa demanda esteve presente nas preocupaçóes dos simpatizantes da TL, como uma forma alternativa de falar da "opção preferencial pelos pobres". Assim, o religioso concluiu sua narrativa:

(...) porque nós iniciamos em 1967-68 ao ponto de sermos chamados de "padres de passeata”, porque acompanhávamos os estudantes da UNE nas manifestaçóes estudantis, que possuíam questôes ideológicas boas (...) Não assustava se o bispo de Belo Horizonte torcia pelo Galo (Atlético Mineiro), mas se assustavam quando nós torcíamos pela UNE (risos) ${ }^{32}$.

Setores da Igreja foram tocados pelas dificuldades enfrentadas pelos fiéis, dando vazão às práticas relacionadas à Doutrina Social da Igreja. O envolvimento do padre Luigi Pescarmona com camponeses vítimas da violência motivaram as ameaças de um proprietário rural da área de Teófilo Otoni, que resultou em sua transferência para outra diocese. Em uma entrevista realizada com um camponês sobre a violência contra o padre Luigi por um fazendeiro, em Minas Gerais, foi-nos narrado:

Eu entendia que o sindicato dos trabalhadores rurais não podia ser só um município e que teria

Idem. 
que ser mais ampliado, porque aí é que a gente podia fazer o trabalho no município de Teófilo Otoni, no município de Ataléia, de onde ele também celebrou, o padre Luís celebrou, mas teve que vir correndo para não ser matado lá em Ataléia, (...) É poucos os fazendeiros que não tem pistoleiros contratados nas fazendas deles. E nessa história toda, o padre Luís falava a verdade, como fala até hoje, e um pistoleiro de latifúndio imprensou ele, que saiu correndo. E ele chegou em Teófilo Otoni (...) Na hora que ele saiu o padre pediu mais uma comunidade para celebrar missa e no mesmo dia ele foi celebrar fora de Teófilo Otoni. Eu fui encontra ele lá e ele estava desfigurado, quando eu encontrei ele lá (...) Ele foi lá não só para celebrar, mas para ver se o coraçáo voltava a bater forte e aquela coisa toda, porque naquele momento ele estava fugido do latifúndio ${ }^{33}$.

Em seguida, deu curso à transferência para a Paraíba (1977), tocada pela violência, depois de alguns anos de aprendizagem da língua portuguesa, da necessidade de dissolver um grupo de padres italianos e dos caminhos a serem seguidos na via da TL. Sobre a chegada e a realização do trabalho junto com Dom Marcelo Carvalheira, em uma diocese marcada pela presença de padres estrangeiros (excetuando-se dois brasileiros: Joaquim, de Araruna, e Epitácio, da Serra da Raiz), recordou que a Igreja era mais sacramentalista em 1977. Porém a situação ganhou nova configuração quanto à questão agrária a partir de 1979, quando o monsenhor apresentou

a Dom Marcelo um mapa da Paraíba num isopor, marcando várias comunidades com alfinetes de cabeças coloridas: amarelo, verde, vermelho, 
negro e azul. Eram cinco níveis, que marcavam visualmente a situação da paróquia da catedral de Guarabira, junto com Araçagi, Pilóezinhos, Cuitegi, Alagoinha. Então, apresentei dentro de dois anos, 79 e 80, esse mapa visual, que havia o nome do lugar, o alfinete e a legenda, que trazia um diagnóstico da situação. Suponhamos: comunidade onde só havia terço, novena, festa de padroeiro; comunidades que, além disso, se reunia para discutir os problemas locais; comunidades onde havia discussão e enfrentamentos de problemas e exigências, com reunióes e mobilizações; e, por fim comunidades que são abertamente envolvidas com a questão trabalhista, agrária ou a questáo da mulher, que eram pontuadas com uma cor mais forte, o vermelho, né? Entâo essas cores demonstravam que uma dada comunidade estava ligada a um ou a outro aspecto $^{34}$.

Alguns padres (sobretudo, Cristiano e Leonardo) se empenharam em adquirir experiências no projeto de uma Igreja mais voltada para os problemas dos pobres rurais e urbanos. Monsenhor Pescarmona dedicou-se, prioritariamente, às questóes referentes à organização dos trabalhadores rurais, que denominou de imagem de um tripé: a organização das comunidades, a constituição de chapas para eleiçôes dos sindicatos de trabalhadores rurais isentas da cooptação dos proprietários rurais e as discussóes iniciais sobre um partido ainda novo, o Partido dos Trabalhadores (PT).

A partir de então, várias foram as "estratégias de subversão", no sentido bourdieusiano ${ }^{35}$, adotadas para mitigar as condições de miséria rural, que passaram por obras em algumas comunidades, como pequenos açudes; resistência às expulsóes de camponeses

34 Monsenhor Luigi Pescarmona. Entrevista ao autor.

35 LOYOLA, Maria Andréa. Pierre Bourdieu: entrevistado por Maria A. Loyola. Rio de Janeiro: Eduerj, 2002. 
das terras de trabalho (após a morte do proprietário e da partilha entre os herdeiros, ou das dispensas do trabalho depois da limpeza dos terrenos para o plantio de capim, no caso da expansáo da atividade criatória, ou da cana, que atendia ao setor sucroalcooleiro); coordenaçáo de "entradas" (no sentido de ocupar as terras), em áreas de onde os camponeses haviam sido expulsos; apoio às mobilizaçóes de trabalhadores urbanos, que não tinham um salário digno; romarias da terra; acampamento de camponeses em praças públicas de João Pessoa, com o objetivo de denunciar a lentidáo dos processos de reforma agrária; manifestaçôes em quartéis ou delegacias para denunciar as prisóes arbitrárias de camponeses ou de membros da CPT; realizaçáo de programas de rádio, com o objetivo de fazer uma leitura da Bíblia, sob a ótica da TL; e, por fim, publicação de livros de cânticos com as músicas cantadas pelos camponeses, visando popularizá-las para que fossem também cantadas nas missas.

A partir das narrativas do monsenhor, pudemos verificar que o trabalho na CPT e com os camponeses se estendeu do final da década de 1970 até os anos da década de 1990. Sua militância ao lado dos camponeses resultou em tentativas de atentados contra sua vida, além de ameaças de morte, processos com o fim de conter o trabalho com os camponeses, acusaçóes de estar organizando movimentos com táticas de guerrilha; além de violências simbólicas ${ }^{36}$. $\mathrm{O}$ monsenhor respondeu vários processos

36 Para Bourdieu (Razóes..., op. cit., p. 171), "A violência simbólica é essa violência que extorque submissões que sequer são percebidas como tais, apoiando-se em 'expectativas coletivas', em crenças socialmente inculcadas. Como a teoria da magia, a teoria da violência simbólica apoiando-se (...) em uma teoria da produção da crença, do trabalho de socialização necessário para produzir agentes dotados de esquemas de percepção e de avaliação que lhes farão perceber as injunções inscritas em uma situação, ou em um discurso, e obedecê-las". A violência simbólica assume o aspecto de uma "persuasão clandestina", sendo implacável por fazer parte da "ordem das coisas" servindo como esteio à dominação e à política (BOURDIEU, Pierre; WACQUANT, Löic. Respuestas: por una Antropología reflexiva. Mexico (DF): Ed. Grijalbo, 1995, p. 120). O Padre Luigi narrou-nos o uso de adjetivaçóes por setores relacionados às classes dominantes agrárias (e conseguimos também atestar em processos e jornais), com o intuito de comprometer, diante da sociedade civil, o trabalho realizado com os camponeses: "padreco filho da puta" (por querer tomar "as terras dos outros"), "padre comunista" (porque "fazia política"), "terrorista" e "palestino" (pois andava com camponeses "armados" com foices e facóes) e que "tinha um caso com uma jovem advogada" (como forma de desacreditá-lo diante dos fiéis, em virtude de um questionamento moral). 
na Justiça, inclusive um de expulsão baseado na extinta Lei de Segurança Nacional, que virou jurisprudência no final da década do ano de 1990.

A disposição dos proprietários para praticar violências resultou na morte de um participante de uma Romaria da Terra e da presidente do Sindicato de Trabalhadores Rurais de Alagoa Grande (1983); torturas de camponeses; tiros de carabinas de calibre 12 contra mulheres e crianças (Dona Inês e Campo de Santana); prisôes arbitrárias; violências que resultaram em abortos em áreas em que camponeses sofreram processos de despejos; necessidade de cirurgias reparadoras em crianças após a desocupação de áreas; destruiçóes de casas e de plantios, entre outras.

Contudo, apesar das situaçôes de violência física ou simbólica, as classes dominantes agrárias ${ }^{37}$, no Agreste e no Brejo paraibanos, criaram estratégias para conservar seus patrimônios, por meio de manobras jurídicas, do uso da imprensa ou mesmo de uma opçáo católica antissocialista através de mençóes a um modelo de Igreja e de religiosos afeitos unicamente aos ritos ou, quando vinculados à política, à política dos proprietários de terra ou dos grupos conservadores. Um exemplo clássico foi o de Frei Damiăo, que, em suas pregaçóes pelo Nordeste com sua prática missionária, combatia todas as formas de socialismo e, com alguma frequência, aparecia em palanques em campanhas eleitorais ${ }^{38}$ de políticos associados aos proprietários de terras ou às oligarquias regionais, como no caso de Fernando Collor de Mello.

Em contrapartida, a organizaçáo da CPT e dos camponeses

37 Referimo-nos aqui às fraçôes dos proprietários de terra assentados historicamente em latifúndios, que remontam ao Século XIX, com atividades produtivas consorciadas pela produção de cana-de-açúcar e/ou pecuária, mesmo durante a fase de modernização agrícola com o PROALCOOL. Manifestaram-se como classe no campo político, em momentos como os processos eleitorais, na contençâo das Ligas Camponesas (década de 1960), no combate às açóes da Pastoral da Terra, nas décadas de 1980 e 1990, usando artifícios junto ao Judiciário (local e nacional) e da imprensa como forma de reproduzir o poder político. Cf. PAIVA NETO, Francisco Fagundes. Reforma agrária e justiça. Anais do 35. Encontro anual da ANPOCS, 2011. Para uma leitura sobre a classe dominante agrária, ver: MENDONÇA, Sônia Regina de. A classe dominante agrária: natureza e comportamento (1964-1990). São Paulo: Expressáo Popular, 2006.

38 Sobre essa questão, ver: CRUZ, João Everton da. Frei Damiáo: a figura do conselheiro no Catolicismo Popular do nordeste brasileiro. Belo Horizonte: Dissertaçáo de Mestrado em Ciências da Religiáo/Pontifícia Universidade Católica de Minas Gerais, 2010, p. 11-12. 
resultou em cerca de 48 assentamentos na área da Diocese de Guarabira. A partir da luta pela terra, com a concretização da reforma agrária, coube à $\mathrm{CPT}$ captar recursos nas entidades estrangeiras e fazer a mediação com o Estado, com o objetivo de facilitar e garantir o êxito de outra fase na construção e na consolidação dos assentamentos, a chamada "luta na terra", para dar viabilidade a um projeto de reforma da sociedade, em um tempo de tantos impactos sobre os camponeses, em decorrência da mundialização e do agronegócio.

\section{REFERÊNCIAS}

BETTO, Frei. Batismo de sangue. 6.ed. Rio de Janeiro: Civilização Brasileira, 1983.

BOURDÉ, Guy; MARTIN, Hervé. As escolas históricas. Mira-Sintra; Mem Martins: Publicaçôes Europa-América, 1983.

BOURDIEU, Pierre; WACQUANT, Löic. Respuestas: por una Antropología reflexiva. México (DF): Ed. Grijalbo, 1995.

BOURDIEU, Pierre. Esboço da teoria e da prática. In: ORTIZ, Renato (org.). Pierre Bourdieu - Sociologia. Trad. Paula Monteiro. 2.ed. São Paulo: Ática, 1994.

BOURDIEU, Pierre. Razóes práticas. Campinas: Papirus, 1996.

CAMPO, German Guzman. Camilo, el cura guerrillero. Bogotá: Servicios Especiales de Prensa, 1967.

CONNERTON, Paul. Como as sociedades recordam. Lisboa: Celta, 1993.

CRUZ, João Everton da. Frei Damiáo: a figura do conselheiro no Catolicismo Popular do nordeste brasileiro. Belo Horizonte: 
Dissertação de Mestrado em Ciências da Religiāo/Pontifícia Universidade Católica de Minas Gerais, 2010.

FENTRESS, James; WICKHAM, Chris. Memória social. Lisboa: Teorema, 1992.

FORTES, Carolina Fortes. A produção literária dominicana no Século XII: uma breve visão sobre a hagiografia. In: COSTA, Sandro da, SILVA; Andréia C. L. F. da; SILVA, Leila R. (orgs.). Atas do Ciclo: a tradiçáa monástica e o franciscanismo. Rio de Janeiro: UFRJ/IFCS, 2003.

GRASSI, Luigi Maria. La tortura di Alba e dell'albense (1944-1945). Alba: San Paolo, 3.ed., 1994.

GRIBAUDI, Maurizio. Escala, pertinência, configuração. In: REVEL, Jacques (org.). Jogos de escala. Rio de Janeiro: Editora FVG, 1998, p121-150.

HOBSBAWM, Eric. Era dos extremos: o breve Século XX. São Paulo: Companhia das Letras, 1995.

LE BRETON, Binka. A dádiva maior: a vida e a morte corajosas da irmã Dorothy Stang. Editora Globo, 2008.

LE BRETON, Binka. Todos sabiam: a morte anunciada de Padre Josimo. Ediçóes Loyola, 2000.

LE GOFF, Jacques. Sáo Francisco de Assis. Rio de Janeiro: Record, 2001.

LE GOFF, Jacques. Sáo Luís. Rio de Janeiro: Record, 2002.

LEVI, Giovanni. A herança imaterial: trajetória de um exorcista no Piemonte do Século XVII. Tradução: Cynthia M. de Oliveira. Rio de Janeiro: Civilização Brasileira, 2000. 
LEVI, Giovanni. Usos da biografia. In: FERREIRA, Marieta Moraes; AMADO, Janaína. Usos e abusos da história oral. Rio de Janeiro: Editora da FGV, 1996.

LOYOLA, Maria Andréa. Pierre Bourdieu: entrevistado por Maria A. Loyola. Rio de Janeiro: Eduerj, 2002.

LUPO, Salvatore. Il fascismo: la politica in um regime totalitario. Roma: Donzelli Editore, 2005.

MAESTRI, Mário e CANDREVA, L. Antonio Gramsci. São Paulo: Expressão Popular, 2001.

MAINWARING, Scott. A Igreja Católica e a política no Brasil (1916-1985). São Paulo: Brasiliense, 1989.

MENDONÇA, Sônia Regina de. A classe dominante agrária: natureza e comportamento (1964-1990). Sáo Paulo: Expressão Popular, 2006.

MENEZES, Marilda Aparecida de. Redes e enredos nas trilhas dos migrantes. Rio de Janeiro: Relume Dumará; João Pessoa: EDUFPB, 2002.

MODONESI, Massimo. Subalternidade, antagonismo, autonomia. Buenos Aires: Consejo Latinoamericano de Ciencias Sociales - CLACSO; Prometeo Libros, 2010.

MORADIELLOS, Enrique. Las caras de Clío. Madri: Siglo XXI Editores, 2001.

MURPHY, Roseanne. Mártir da Amazônia: a vida de Dorothy Stang. São Paulo: Paulus, 2008.

PAIVA NETO, Francisco Fagundes. A Ação Católica: a 
resistência piemontesa ao fascismo (1933-1944). Histórica - Revista Eletrônica do Arquivo Público do Estado de Sáo Paulo, n. 58, maio 2013.

PAIVA NETO, Francisco Fagundes. A trajetória religiosa-política do padre Luigi Pescarmona (1960-2000): entre o habitus partisáo e o assistencial. Campina Grande: Tese de Doutorado em Ciências Sociais/Universidade Federal de Campina Grande, 2012.

PAIVA NETO, Francisco Fagundes. Reforma agrária e justiça. Anais do 35. Encontro anual da ANPOCS, 2011. (Disponível em: <http://www.anpocs.org/portal/index.php?option=com_docman\&task $=$ cat_view\&gid $=181 \&$ limit $=20 \&$ limitstart $=0$ \&or der=hits\&dir=ASC\&Itemid=280 >. Acesso em 05/02/2014).

PEREIRA, Nilo. Dom Vital e a questáo religiosa no Brasil. Recife: Imprensa Universitária/UFPE, 1996.

REVEL, Jacques. A história ao rés-do-chão. In: LEVI, Giovanni. A herança imaterial. Rio de Janeiro: Civilizaçáo Brasileira, 2000, p. 7-37.

SALTALAMACCHIA, Homero. La historia de vida: reflexiones a partir de una experiencia de investigación. Puerto Rico: Ediciones SIJUP, 1992.

SANTANA, Manoel Henrique de Melo. Padre Cícero do Juazeiro: condenação e exclusão eclesial à reabilitação histórica. Maceió: EDUFAL, 2009.

SASSOON, Donald. Mussolini e a ascensão do fascismo. Tradução Clóvis Marques. Rio de Janeiro: Agir, 2009.

SILVA, Claudia Neves da. Igreja católica, assistência social e caridade: aproximaçôes e divergências. Sociologias, Porto Alegre, ano 8, n15, p.326-351, jan.-jun. 2006. 
SILVEIRA, Ildefonso e REIS, Orlando dos (orgs.). Sáo Francisco de Assis: escritos e biografias de São Francisco de Assis. Petrópolis: Vozes, 2000.

SOBREIRA, Azarias. O Patriarca de Juazeiro. Petrópolis: 1968.

\section{ENTREVISTAS:}

Monsenhor Luigi Pescarmona, coordenador da CPT/Guarabira. Entrevistas concedidas ao autor entre 2008 e 2010.

Sílvio Rodrigues, ex-sindicalista. Entrevista concedida ao autor em Montes Claros-MG, 19 de maio de 2010. 